profusion that all the biological institutions of Europe and tho United States can, it is said, bo supplied without stint from this source.

\section{New Antarctic Expeditions}

Two American expeditions to the antarctic are announced in the Polar Record for July. The Ellsworth expedition has for its object a trans-antaretic flight to discover the nature of the land between the Ross and Weddell Seas. From a base, which it is hoped to establish in the Bay of Whales, Ross 13arrier, in December, it is proposed to fly to the south of the Weddell Sea and back, without landing on the way. This flight of 2,900 miles is expected to take ten hours. The expedition does not expect to spend more than a week at its base and is not to winter. On the other hand, Admiral R. F. Byrd proposes to winter in the south, taking with him a large number of dogs and several motor tractors besides an aeroplane. His expedition will have a personnel of about forty and is planned to sail this autumn. Details are not yet announced but the plans includo a flight to the south pole and exploratory work to the east of the Ross Sea.

\section{New Islands in the Arctic}

The Society for Cultural Relations has issued a report stating that a new group of islands has been discovered in the arctic by the expedition aboard the icebreaker Sibiryak. The news was conveyed by a radiogram from Prof. Wiese, head of the expedition, to the Arctic Institute in Leningrad. The islands lie to the south-west of the Izvestia, a group of islands south-west of Solitude Island discovered last year by tho icebreaker Rusanov.

\section{Carnegie Institution of Washington}

The report of the President of the Carnegie Institution of Washington for 1932 contains a brief account of the broad lines upon which the Institution has organised its distribution of grants. It aims at the greatest service through investigation, and at the same time the fullest uso of the advances made. "Attainment of the highest values in an institution devoted to research depends in a measure upon the extent to which touch can be maintained with the fields of application, stimulation, and spiritual refreshment through which they may contribute to life." Keeping this aspect in view, the Carnogie Institution has recognised three lines along which it may aid the use of research contributions. First, it has formulated a scheme for permanent and detailed record of results coming from researches, so that they may be available to specialists in all fields of science. Secondly, continued effort has been directed toward study of the broader interpretation of work accomplished, and toward statement of conclusions in such manner that they may have the widest possible research and educational value. Thirdly, there is now being developed a series of studies, designed to review research activities having application aspects so important that united offort of all contributing agencies may be desirable.

\section{Agricultural Publications}

The third annual report (1931-1932) of the Executive Council of the Imperial Agricultural Bureaux (London: H.M. Stationery Office. 1s. net) shows that important developments have taken place during the year under review. The outstanding feature of the report is that it marks for the first time the regular issue of journals from practically all the eight bureaux. These journals embody information abstracted from scientific periodicals in almost overy language and from almost every country. Horticultural Abstracts is issued by the Buroau of Fruit Production at East Malling, the Veterinary Bulletin monthly from Weybridge, List of Publications Relating to Soils and Fertilisers monthly from Rothamsted, Plant Breeding Abstracts quarterly from Cambridge, Herbage Abstracts quarterly from Aberystwyth, Bulletin on Animal Genetics quarterly from Edinburgh. Abstracts on agricultural parasitology, which are prepared by the Bureau at St. Albans, appear in the Quarterly Journal of Helminthology, whilst the journal from AberdeonNutrition Abstracts and Reviews-reveals co-operation between the Medical Research Council, the trustees of the Reid Library and the Executive Council of the Imperial Agricultural Bureaux. The analysis of the year's expenditure bears testimony to the large part played by these journals in the work of the Bureaux. Moro than ninety per cent of the gross expenditure has been incurred in the examination, abstraction and distribution of scientific information, in the purchase of necessary scientific books and periodicals and in the publication of a number of special bibliographies on subjects of particular interest.

\section{Epidemiological Studies on Scarlet Fever}

THE deaths from scarlet fever in England and Wales in 1851 numbered 13,634 , whereas in 1931 with a larger child-population they numbered only 540. This remarkable change in mortality is the subject of a study by Miss Hilda Woods (Med. Res. Council, Sp. Rep. Serios, No. 180. 1933). The diminution of scarlet fever deaths appears to be due ossentially to lessened severity of the disease, and not to any general dirninution in prevalence, and no evidence has been found to prove that hospital isolation has been effectivo in reducing either the prevalence or the mortality. The spread of scarlet fever has been attributed to various factors, but none seems to be generally applicable. Thus, in London scarlet fever is more prevalent in overcrowded arcas, in Birmingham the greatest incidence is among the better class artisans, in Glasgow as overerowding increases tho attack-rate tends to diminish. In London there is a significant association between wet years and low prevalence, but no such association obtains in Liverpool, Manchestor, or Birmingham.

\section{The Pasteur Institute of Southern India, Coonoor}

THE annual report for 1931 of the Director, Major Iyengar, of the Pasteur Institute of Southern India, 